Medicine Bundle 



\title{
Medicine Bundle
}

Indian Sacred Performance and

American Literature, 1824-1932

\author{
Joshua David Bellin
}

University of Pennsylvania Press

Philadelphia 
Copyright $\odot 2008$ University of Pennsylvania Press

All rights reserved. Except for brief quotations used for purposes of review or scholarly citation, none of this book may be reproduced in any form by any means without written permission from the publisher.

Printed in the United States of America on acid-free paper

$\begin{array}{llllllllll}10 & 9 & 8 & 7 & 6 & 5 & 4 & 3 & 2 & 1\end{array}$

Published by

University of Pennsylvania Press

Philadelphia, Pennsylvania 19104-4112

A Cataloging-in-Publication Record is available from the Library of Congress

ISBN-13: 978-0-8122-4034-4

ISBN-10: 0-8122-4034-0 
For Geraldine Murphy 
